\title{
Human immunodeficiency viruses in patients attending a sexually transmitted disease clinic in London, 1982-7
}

\author{
C Loveday, L Pomeroy, I V D Weller, J Quirk, A Hawkins, H Williams, A Smith, P Williams, \\ R S Tedder, $M$ W Adler
}

Abstract

Objective-To determine the prevalence of infection with the human immunodeficiency virus (HIV) in all patients attending a London sexually transmitted disease clinic over four weeks at the end of 1987 and to see how it varied from that in similar samples studied between 1982 and 1986.

Design-Anonymous testing of serum samples from consecutive heterosexual and homosexual patients having routine serological investigations for syphilis. Testing was for anti-HIV-I, anti-HIV-II, and hepatitis B core antibody (anti-HBc) and P24 antigen. Age, nationality, sexual orientation, and past sexually transmitted diseases were recorded for each patient. Gonorrhoea rates by quarters were analysed among homosexual and bisexual men and heterosexual men and women from 1981 to 1987.

Setting-Outpatient department of genitourinary medicine.

Patients - A total of 1074 patients attending consecutively for syphilis serology. Thirty five homosexual and bisexual men were excluded (these were regular attenders as part of a prospective study of the natural course of HIV infection).

Measurements and main results-The prevalence of anti-HIV-I in homosexual and bisexual men in 1987 was $25.6 \%(64 / 250)$. Results in the same clinic population between 1982 and 1984 had shown a rise in prevalence, which flattened out in 1985-6 and continued at that level. Among heterosexual attenders in 1987 the prevalence of anti-HIV-I was $1 \%$ (women 4/412; men 4/377), which contrasted with a prevalence of $0.5 \%$ (women 2/395; men $3 / 757$ ) in January 1986. One homosexual man was seropositive for anti-HIV-II and seronegative for anti-HIV-I. Among homosexual and bisexual men the rate of gonorrhoea had declined by an average of $2.7 \%$ a year since 1981, such that by 1987 - and for the first time in the clinic - there was no significant difference in the rates between these men and heterosexual men and women.

Conclusions - The appearance of HIV-I infection among heterosexuals indicates a need for more aggressive education programmes and intervention strategies along the lines adopted for homosexual men. Surveillance for HIV-II infection is needed to provide information for future policy in national screening programmes.

University Collegelogy ty College and Middlesex School of Medicine, London

A Hawkins, BSC, medical laboratory scientific officer $\mathrm{H}$ Williams, BSC, research medical laboratory scientific officer

A Smith, PHD, research fellow R S Tedder, MRCP, consultant in virology

Correspondence to: $\mathrm{Dr}$ Weller.

BrMed f 1989;298:419-22 disease clinics. ${ }^{1-3}$ In the United Kingdom most infections have been in homosexual men, but the spread of infection has declined among homosexuals in London in association with a reduction in their numbers of sexual partners and the adoption of safer sexual practices. ${ }^{+}$The potential for increasing cases in the heterosexual community will lie initially with intravenous drug users, bisexual men, and to a less extent haemophiliacs.

In addition to HIV-I, HIV-II - a similar but antigenically different virus - is endemic in countries in west Africa ${ }^{5}$ and produces similar clinical features. It has also been detected in Europeans who have lived or had sexual partners in those areas; two cases in France ${ }^{6}$ and one in the United States ${ }^{7}$ represent the only cases not directly linked to the source of this virus.

The aim of this study was to examine the continuing trends in the prevalence of infection with HIV (types I and II) and the incidence of gonorrhoea as a surrogate marker of change in sexual behaviour in patients attending our sexually transmitted disease clinic. ${ }^{8}$ The findings were compared with similar sampling carried out in March 1982, July 1984, April and May 1985, January 1986, and November and December $1986 .^{49}$ We hoped that the results would allow us to develop more appropriate intervention and educational strategies among our population.

\section{Patients and methods}

During four weeks in November and December 1987 we studied 1074 consecutive heterosexual and homosexual patients attending the department of genitourinary medicine at the Middlesex Hospital, London, and having routine serological tests for syphilis. As in previous sampling, homosexual men asked to attend regularly as part of a prospective study of the course of HIV infection (HIV study cohort) were excluded $(n=35)$. The eventual sample therefore totalled 1039. The clinic appointment system had resulted in an unchanged proportion of new to follow up attenders. Age, nationality, sexual orientation, and past sexually transmitted diseases were extracted from the notes on to separate study recording sheets. Anonymity was ensured by removing the patient's clinic number from each record sheet and giving it and the serum sample code numbers before serological results were analysed. Serum samples were tested for anti-HIV-I by gelatin particle agglutination (SerodiaHIV, Fujirebio Inc) and the results confirmed by competitive enzyme linked immunosorbent assay (ELISA; Wellcozyme, Wellcome); for anti-HIV-II by competitive ELISA $^{10}$ and western blotting (Dupont Ltd); for hepatitis B core antibody (anti-HBc) by passive haemagglutination assay (Green Cross Corporation), the results being confirmed by competitive ELISA (Wellcozyme); and for HIV P24 antigen by ELISA.

Gonorrhoea rates by quarter (numbers of patients with gonorrhoea over total number of patients attending) were analysed among homosexual and bisexual men and heterosexual men and women from 1981 to 1987.

Data were analysed by the Mann-Whitney U test for differences in continuous variables and the $\chi^{2}$ test for differences in proportions. 
Results

Of the 1039 patients studied, 789 were heterosexual (412 women, 377 men) and 250 homosexual or bisexual (table I). Sixty four of the 250 homosexual and bisexual men studied were anti-HIV-I seropositive, a prevalence of $25 \cdot 6 \%$; among British men considered alone the prevalence was also $25 \cdot 6 \%$ (54 of 211 ).

TABLE I-Demographic features of heterosexual, homosexual, and bisexual men and women seen in 1987

\begin{tabular}{lccc}
\hline & $\begin{array}{c}\text { Heterosexual } \\
\text { men }\end{array}$ & $\begin{array}{c}\text { Homosexual/ } \\
\text { bisexual men }\end{array}$ & $\begin{array}{c}\text { Heterosexual } \\
\text { women }\end{array}$ \\
\hline $\begin{array}{l}\text { No of patients } \\
\text { No }(\%) \text { non-United } \\
\text { Kingdom born }\end{array}$ & 377 & 250 & 412 \\
$\begin{array}{c}\text { No }(\%) \text { anti-HIV } \\
\text { positive }\end{array}$ & $76(20 \cdot 2)$ & $39(15 \cdot 6)$ & $94(22 \cdot 8)$ \\
$\begin{array}{c}\text { Median age (range) in } \\
\text { years }\end{array}$ & $28(18-1)$ & $64(25 \cdot 6)$ & $4(1 \cdot 0)$ \\
$\begin{array}{c}\text { Median No of past } \\
\text { sexually transmitted } \\
\text { diseases (range) }\end{array}$ & $1(0-19)$ & $30(18-62)$ & $25(17-67)$ \\
$\begin{array}{c}\text { No }(\%) \text { of patients } \\
\text { anti-HBc positive }\end{array}$ & $27(7 \cdot 2)$ & $111(44 \cdot 4)$ & $40(9 \cdot 7)$ \\
\hline
\end{tabular}

There were no significant differences in age, numbers of past sexually transmitted diseases, and prevalence of anti-HBc between the sample studied and the samples in previous surveys. There was, however, a significantly lower proportion of non-United Kingdom nationals in $1987(39 / 250 ; 15 \cdot 6 \%)$ as compared with $1982(46 / 153$; $30 \cdot 1 \%)\left(\mathrm{p}<0 \cdot 001 ; \chi^{2}, \mathrm{df}=1\right)$.

One patient, a 33 year old homosexual man resident in the United Kingdom, was found to be seropositive for anti-HIV-II by competitive ELISA and western blotting. He was seronegative for anti-HIV-I (table II). $\mathrm{He}$ described two previous sexually transmitted diseases, was attending for follow up of urethral gonorrhoea, and his serum contained anti-HBc.

TABLE II-Reactivity of serum from patient infected with HIV-II in diverse assays for anti-HIV-I

\begin{tabular}{|c|c|c|c|}
\hline \multirow[b]{2}{*}{ Assay } & \multirow[b]{2}{*}{ Cut off } & \multicolumn{2}{|c|}{$\begin{array}{l}\text { Serum from HIV-II } \\
\text { infected patient }\end{array}$} \\
\hline & & Test result & Interpretation \\
\hline Abbott (recombinant antigen) & $0 \cdot 210 \dagger$ & $0 \cdot 164$ & Negative \\
\hline $\begin{array}{l}\text { Dupont (tissue culture derived } \\
\text { antigen) }\end{array}$ & $0.531+$ & $0 \cdot 391$ & Equivocal \\
\hline Dupont $(\text { recombinant antigen })^{\star}$ & $0.333+$ & 1.069 & Positive \\
\hline Wellcozyme ${ }^{\star}$ & $0.382 \dagger$ & 0.527 & Negative \\
\hline Wellcozyme (monoclonal) & $0.451 \dagger$ & $0 \cdot 314$ & Positive \\
\hline $\begin{array}{l}\text { Fujirebio passive agglutination } \\
\text { assay }\end{array}$ & $>1 / 16$ & $<1 / 16$ & Negative \\
\hline
\end{tabular}

* Data provided by Dr H Gunson, Manchester Blood Transfusion Centre. tOptical density at wavelength defined by manufacturer.

Ability of several of the more widely used assays for anti-HIV-I to detect this crum varied. Dupont assay based on recombinant antigen was the the serum varied. Dupon assay based on recombinant antigen was the onl antiglobulin assyy reliably; surprisingly, Wellcozym ample. These results may have that can be used for screening in United Kingdom
Four of 377 heterosexual men were anti-HIV-I seropositive (tables I and III). Two were British, one was European, and the fourth South American; all were resident in the United Kingdom. Only one gave a history of past sexually transmitted disease, and three were anti-HBc positive. On the day that they were entered into the study two had a sexually transmitted disease (one urethral gonorrhoea, the other pubic lice). One patient, who did not have a sexually transmitted disease, was an intravenous drug user, and the remaining three had no known risk factors for HIV infection.

Four of 412 women tested were anti-HIV-I seropositive (tables I and III). Two were British, one was born in Africa, and one was a European; all were resident in the United Kingdom. Two had had previous sexually transmitted diseases. On the day of the study one patient was a contact of non-specific urethritis, a second had genital warts, and a third presented requesting an HIV test. Three were anti-HBc seronegative and the one anti-HBc seropositive patient had been an intravenous drug user up to three years before.

The prevalence of anti-HIV-I among British homosexual and bisexual men (figure; table IV) attending our department rose dramatically from $3 \cdot 7 \%(4 / 107)$ in
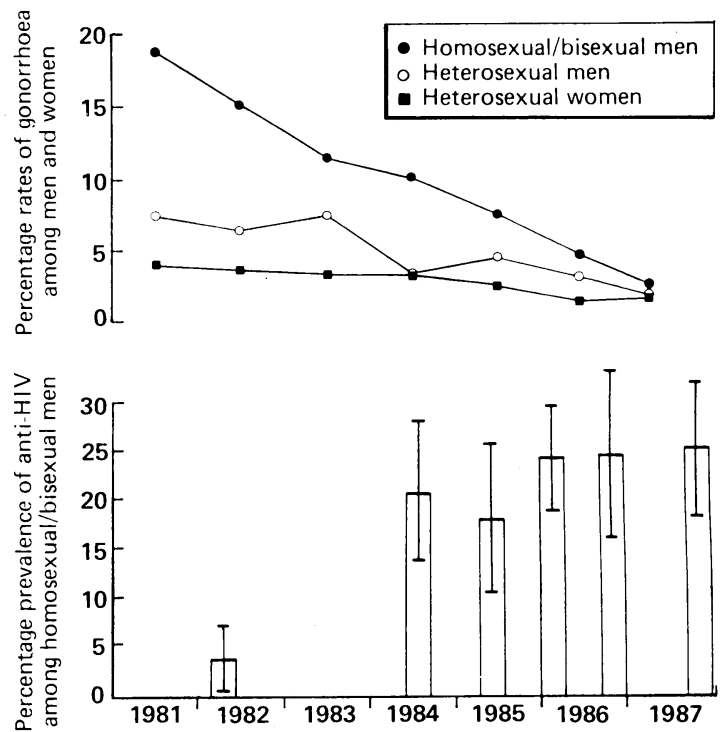

Prevalence of anti-HIV and rates of gonorrhoea in men and women attending the Middlesex Hospital, London, during 1981-7. (Bars are $95 \%$ confidence limits)

1982 to $21 \cdot 0 \%(26 / 124)$ in 1984 but subsequently remained unchanged. Three of $757(0.4 \%)$ heterosexual men tested in January and December 1986 were anti-HIV-I seropositive; one had had several sexual contacts in central Africa and one had had sexual intercourse with several prostitutes in London. Two of

TABLE III - Demographic features of anti-HIV positive heterosexual men and women

\begin{tabular}{|c|c|c|c|c|c|c|c|c|}
\hline & \multicolumn{4}{|c|}{ Men } & \multicolumn{4}{|c|}{ Women } \\
\hline & Case 1 & Case 2 & Case 3 & Case 4 & Case 5 & Case 6 & Case 7 & Case 8 \\
\hline $\begin{array}{l}\text { Age (years) } \\
\text { Country of birth }\end{array}$ & $\begin{array}{c}34 \\
\text { United } \\
\text { Kingdom }\end{array}$ & $\begin{array}{c}29 \\
\text { United } \\
\text { Kingdom }\end{array}$ & $\begin{array}{c}29 \\
\text { Europe (United } \\
\text { Kingdom resident) }\end{array}$ & $\begin{array}{c}31 \\
\text { South America } \\
\text { (student) }\end{array}$ & $\begin{array}{c}23 \\
\text { Africa(United } \\
\text { Kingdom resident) }\end{array}$ & $\begin{array}{c}33 \\
\text { Europe (United } \\
\text { Kingdom resident) }\end{array}$ & $\begin{array}{c}22 \\
\text { United } \\
\text { Kingdom }\end{array}$ & $\begin{array}{c}26 \\
\text { United } \\
\text { Kingdom }\end{array}$ \\
\hline $\begin{array}{l}\text { No of past sexually } \\
\text { transmitted diseases }\end{array}$ & 0 & 0 & 0 & 1 & 0 & 0 & $1^{\star}$ & $3^{\star}$ \\
\hline $\begin{array}{l}\text { Diagnosis (on day of } \\
\text { testing) }\end{array}$ & Pubic lice & $\begin{array}{l}\text { Urethral } \\
\text { gonorrhoea }\end{array}$ & No appreciable disease & Not known & $\begin{array}{l}\text { Non-specific urethritis } \\
\text { contact in United } \\
\text { Kingdom }\end{array}$ & $\begin{array}{l}\text { Presented requesting } \\
\text { anti-HIV testing }\end{array}$ & Warts & $\begin{array}{c}\text { No appreciable } \\
\text { disease }\end{array}$ \\
\hline $\begin{array}{l}\text { Anti-HBc } \\
\text { HIV risk }\end{array}$ & $\begin{array}{l}\text { Positive } \\
\text { None }\end{array}$ & $\begin{array}{l}\text { Negative } \\
\text { None }\end{array}$ & $\begin{array}{c}\text { Positive } \\
\text { Intravenous drug } \\
\text { usage }\end{array}$ & $\begin{array}{l}\text { Positive } \\
\text { None }\end{array}$ & $\begin{array}{l}\text { Negative } \\
\text { None }\end{array}$ & $\begin{array}{l}\text { Negative } \\
\text { None }\end{array}$ & $\begin{array}{l}\text { Negative } \\
\text { None }\end{array}$ & $\begin{array}{c}\text { Positive } \\
\text { Intravenous } \\
\text { drugs usage }\end{array}$ \\
\hline
\end{tabular}

*Includes one episode of vaginal candidiasis.

tLast intravenous drug usage more than three years before. 
$395(0 \cdot 5 \%)$ women tested in January 1986 were antiHIV-I seropostive; one had a recognised risk factor and the other had had only one sexual partner in the previous eight months. ${ }^{+}$In the samples before January 1986 no anti-HIV-I seropositive patient was found among heterosexual men and women. In the 1039 patients studied no further HIV infections were identified by using the P24 antigen assay than had been found by anti-HIV assays.

Among homosexual and bisexual men rates of gonorrhoea (figure; table IV) had fallen significantly from $19 \cdot 2 \%(1162 / 6053)$ in 1981 to $2 \cdot 3 \%(111 / 4826)$ in $1987\left(\mathrm{p}<0.001 ; \gamma^{2}, \mathrm{df}=1\right)$, a decline of $2 \cdot 7 \%$ a year.

TABLE IV-Numerical prevalence of anti-HIV and rates of gonorrhoea in men and women attending the Middlesex Hospital, London, during 1981-7

\begin{tabular}{lccccccc}
\hline & 1981 & 1982 & 1983 & 1984 & 1985 & 1986 & 1987 \\
\hline $\begin{array}{l}\text { Gonorrhoea among men and women: } \\
\text { Heterosexual men }\end{array}$ & $535 / 7106$ & $461 / 6841$ & $366 / 6801$ & $312 / 6316$ & $338 / 7416$ & $224 / 8036$ & $124 / 6610$ \\
$\begin{array}{l}\text { Heterosexual women } \\
\text { Homosexual/bisexual men }\end{array}$ & $310 / 8054$ & $268 / 7351$ & $227 / 7492$ & $206 / 7381$ & $223 / 9605$ & $122 / 10431$ & $100 / 9177$ \\
$\begin{array}{c}\text { Prevalence of anti-HIV among } \\
\text { homosexual and bisexual men }\end{array}$ & $1162 / 6053$ & $1010 / 6026$ & $864 / 6081$ & $696 / 6588$ & $494 / 6899$ & $226 / 5556$ & $111 / 4826$ \\
& ND & $4 / 107$ & ND & $26 / 124$ & $17 / 94$ & $61 / 249$, & $64 / 250$ \\
& & & & & & $25 / 99$ & \\
\hline
\end{tabular}

$\mathrm{ND}=$ Not done

In heterosexual men and women rates had fallen significantly from $7 \cdot 5 \%(535 / 7106)$ and $3 \cdot 8 \%(310 /$ $8054)$ respectively in 1981 to $1.9 \%(124 / 6610 ; \mathrm{p}<0.01$, $\left.\chi^{2}, \mathrm{df}=1\right)$ and $1 \cdot 1 \%\left(100 / 9177 ; \mathrm{p}=0 \cdot 05, \chi^{2}, \mathrm{df}=1\right)$ in 1987 , a decline of $0.9 \%$ a year in heterosexual men and $0.4 \%$ a year in women. For the first time in our clinic, by March 1987 there was no significant difference in rates of gonorrhoea between homosexual and bisexual men and heterosexual men and women.

The prevalence of anti-HBc in heterosexual men and women $(7 \cdot 2 \%$ and $9 \cdot 7 \%$; table I) was substantially unchanged as compared with our survey in May 1985 , when the prevalence rates were $8 \cdot 8 \%$ and $9 \cdot 2 \%$ respectively. Exclusion of non-United Kingdom nationals gave prevalences of $3.6 \%$ and $4.6 \%$ in heterosexual men and women in this survey.

\section{Discussion}

The prevalence of anti-HIV-I in homosexual and bisexual men attending our clinic had not changed significantly since 1984 . There were no significant differences in age, numbers of past sexually transmitted diseases, and prevalence of anti-HBc among samples. Since 1982 there had been a decrease in the incidence of gonorrhoea in all groups, but particularly in homosexual and bisexual men. It was among that group that the greatest alteration in sexual behaviour was documented, and probably it was this that so considerably altered the rate at which new HIV infections were occurring. In 1987 the prevalence of anti-HIV-I among heterosexual men and women attending our clinic was $1 \cdot 1 \%$ and $1 \cdot 0 \%$ respectively. When we excluded intravenous drug users the rates fell to $0.8 \%$ and $0.7 \%$. The prevalence was lower than found in a similar study in a sexually transmitted disease clinic in Baltimore, United States, which reported a prevalence of $2 \cdot 7 \%$ in heterosexual men and $1.8 \%$ in women. "Also in the United States $1964(3.9 \%)$ reported cases of AIDS occurred as a result of heterosexual intercourse $\mathrm{e}^{12}$ compared with 44 $(2 \cdot 8 \%)$ in the United Kingdom. ${ }^{13}$ The lower figures in the United Kingdom reflect only that we are three to four years behind the epidemic in the United States and should give us warning that heterosexually acquired HIV infection is bound to increase.

From our results among heterosexual attenders six of eight patients apparently had no identifiable risk factor that would have warranted their inclusion in an HIV risk group. Despite the limitations of anonymous testing and the fact that two of the six patients had evidence of previous exposure to hepatitis $B$, it seems plausible that their infections had been acquired heterosexually. What is inescapable is that all eight patients were sexually active adults, with and without other sexually transmitted infections, and unaware that they were infected or had put themselves at risk of HIV infection. These people constitute a pool of infection from which HIV is likely to disseminate. This is especially so given that usage of condoms among heterosexuals in the United States and Britain is low. The Baltimore study found that over half of the heterosexual men and women surveyed never used condoms with casual sexual partners, and similar results were reported by Sonnex et al from our clinic ${ }^{14}$ and Evans et $a^{15}$ in women attending the west London clinic.

Thus if we extrapolate over a year from a $1.0 \%$ prevalence of HIV-I infection (8/789) in heterosexual men and women attending this clinic and having serological tests for syphilis over four weeks or alternatively assume a $1 \%$ prevalence in all heterosexual diagnoses in the clinic each year (18466) it may be that between 100 and 185 anti-HIV positive heterosexuals are missed in a year. This must cause concern and should lead us to rethink our approach to the care of these groups of patients. Within sexually transmitted disease clinics there is a need for aggressive education of heterosexuals about HIV infection and AIDS. The provision of leaflets, counselling, videos, and testing with consent for evidence of HIV infection should become part of the routine management of heterosexuals attending sexually transmitted disease clinics. Furthermore, it has been argued that a low prevalence of HIV-I infection is an indication for contact tracing to reduce further spread and limit the pool of asymptomatic but infectious people. In the United States the Centers for Disease Control have issued clear guidelines and consider contact tracing to be an important element in the control of HIV infection. ${ }^{16}$

As HIV-II infection was found in one homosexual man attending our clinic and in a sub-Saharan African woman attending a London antenatal clinic, ${ }^{17}$ we believe that continued surveillance for this retrovirus in all patients tested for anti-HIV-I is necessary to provide information for the future policy on the possible expansion of national screening programmes.

This research using anonymous testing has provided valuable data, on the basis of which we are reviewing our present clinic strategies. Similar studies would be invaluable in other clinics and medical settings.

IVDW is a Wellcome Trust senior lecturer in infectious diseases. AH is supported by the Wellcome Trust, JQ by the Frances and Augustus Newman Foundation, and AS by the Wellcome Foundation.

1 Quinn TC, Mann JM, Curran JW, Piot P. AIDS in Africa: an epidemiological paradigm. Science 1986;234:955-63.

2 Piot P, Plummer FA, Rey N-A, et al. Retrospective seroepidemiology of AIDS virus infection in Nairobi populations. F Infect Dis 1987;155:1108-12.

3 Melbye M. Nielesani EK, Bayley A, et al. Evidence for heterosexual transmission and clinical manifestations of human immunodeficiency virus infection and related conditions in Lusaka, Zambia. Lancet 1986;ii: $1113-5$.

4 Carne CA. Weller IVD, Johnson AM. et al. Prevalence of antibodies to human immunodeficiency virus, gonorrhoea rates, and changed sexual behaviour in homosexual men in London. Lancet 1987; ;:656-8.

5 Clavel F, Guetard D, Brun-Vezinet F, et al. Isolation of a new retrovirus from west African patients with AIDS. Science 1986;233:343-6.

6 Brucker G, Brun-Vezinet F, Rosenheim M, et al. HIV-2 infection in two homosexual men in France. Lancet 1987;i:223.

7 Anonymous. AIDS due to HIV 2 infection-New Jersev. MMWR 1988;87: 33-5.

8 Weller IVD, Hindley D, Meldrum J, Adler MW. Gonorrhoea in homosexual men and media coverage of the acquired immune deficiency syndrome in London 1982-3. Br.Med F 1984;289:1041

9 Carne CA, Weller IVD, Sutherland S, et al. Rising prevalence of human Tlymphotropic virus type III (HTLV III) infection in homosexual men in London. Lancet 1985; i: 1261-2.

10 Mabey DGW, Tedder RS, Hughes ASB, et al. Human retroviral infections in The Gambia: prevalence and clinical features. Br Med f 1988;296:83-6.

11 Quinn TC, Glasser D, Cannon RO, et al. Human immunodeficiency virus 
infection among patients attending clinics for sexually transmitted disease. N Engl F Med 1988;318:197-203.

12 Johnson AM. Heterosexual transmission of human immunodeficiency virus. BrMed F 1988;296:1017-20.

13 Communicable Disease Surveillance Centre. Acquired immune deficiency syndrome: United Kingdom, 1982-January 1988. Communicable Disease Report 1988; week 05:3.

14 Sonnex C, Hart GJ, Williams P, Adler MW. Condom use by heterosexuals attending a department of genitourinary medicine: attitudes and behaviour in the light of HIV infection. Genitourin Med (in press).

15 Evans BA, McCormack SM, Bond RA, MacRae KD, Thorp RW. Human immunodeficiency virus infection, hepatitis B virus infection, and sexual behaviour of women attending a genitourinary medicine clinic. $\mathrm{Br}$ Med $\mathcal{J}$ $1988 ; 296: 473-5$.

16 Centers for Disease Control. Public Health Service guidelines for counselling and antibody testing to prevent HIV infection and AIDS. MMWR

17 Heath RB, Grint PCA, Hardiman AF. Anonymous testing of women attending antenatal clinics for evidence of infection with HIV. Lancet 1988; ;:1394.

(Accepted 5 fanuary 1989

\title{
Prevalence of HIV antibody in high and low risk groups in England
}

\author{
Public Health Laboratory Service Working Group
}

\begin{abstract}
Most studies of the spread of HIV infection have centred on homosexuals and intravenous drug users. To estimate the extent of infection in different groups, including heterosexuals, the prevalence of HIV antibody was studied in 34222 subjects tested with consent between October 1986 and December 1987 in England. These included subjects in high risk groups for HIV infection, heterosexuals with partners in the high risk groups and heterosexuals with multiple partners or with no identifiable risk factors. The prevalence was highest in homosexual or bisexual men in London $(15 \cdot 1 \% ; 213 / 1412)$, being $4.0 \%(146 / 3607)$ outside London. The yearly incidence of infection in 632 homosexual or bisexual men without HIV antibody when retested during the study period was $3 \%$. Among intravenous drug users the prevalence of HIV antibody was $5 \cdot 7 \%(36 / 633)$ in London and $1.5 \%(39 / 2562)$ outside. Of 3272 heterosexual subjects tested, whose partner was in a risk group, eight of $515(1.6 \%)$ in London and six of $2757(0 \cdot 2 \%)$ outside were positive for the antibody. Among 20455 heterosexuals with a history of multiple partners or with no declared risk, only six subjects with HIV antibody were identified, two of whom had been infected abroad.

Heterosexual spread of infection in England is evidently still largely confined to subjects whose partner has an identifiable risk.
\end{abstract}

PHLS Working Group United Kingdom have focused on homosexuals A list of members of the group is given at the end of the paper

Requests for reprints and correspondence to: Dr E Miller, PHLS Communicable Disease Surveillance Centre, London NW9 5EQ.

BrMed $\mathcal{F}$ 1989;298:422-3

\section{Introduction}

Previous studies of the prevalence of antibody to the human immunodeficiency virus (HIV) in the attending genitourinary medicine clinics in London and on intravenous drug users in Scotland. ${ }^{1-5}$ We report on the prevalence of HIV antibody among 34222 subjects in various risk groups who consented to be tested by 10 public health laboratories in England between October 1986 and December 1987.

TABLE I-Prevalence of HIV antibody among 34222 subjects according to sex and risk factors, October 1986 to December 1987. ${ }^{\star}$ Total number tested $(n)$ and number positive for HIV antibody/number tested in parentheses

\begin{tabular}{|c|c|c|}
\hline Risk factor & Men & Women \\
\hline $\begin{array}{l}\text { Homosexual or bisexual }(n=5019) \\
\text { Lived in Africa }(n=755) \\
\text { Intravenous drug user }(n=3195) \\
\text { Transfusion or transplant recipient }(n=1336) \\
\text { Heterosexual partner in known risk group }(n=3272) \\
\text { Heterosexual part tner "positive for HIV antibody" }(n=190) \\
\text { Multiple heterosexual partners }(n=6390) \\
\text { No identified risk }(n=14065)\end{array}$ & $\begin{array}{ll}7 \cdot 2 & (359 / 5019) \\
4 \cdot 9 & (25 / 510) \\
2 \cdot 3 & (51 / 2201) \\
0 \cdot 8 & (4 / 506) \\
0 \cdot 2 & (1 / 645) \\
3 \cdot 8 & (2 / 52) \\
0 \cdot 2 & (4 / 2396) \\
0 \cdot 01 & (1 / 8383)\end{array}$ & $\begin{array}{ll}5 \cdot 7 & (14 / 245) \\
2 \cdot 4 & (24 / 994) \\
0 \cdot 4 \quad(3 / 830) \\
0 \cdot 5 \quad(13 / 2627) \\
8 \cdot 0 \quad(11 / 138) \\
0 \cdot 03 \quad(1 / 3994) \\
\quad(0 / 5682)\end{array}$ \\
\hline Tot & $2 \cdot 3(447 / 19712)$ & $0.5(66 / 14510)$ \\
\hline
\end{tabular}

^Excludes 568 subjects with multiple risks ( 22 positive for HIV antibody) and 394 non-sexual contacts (all negative). †Not verified by participating laboratories.
TABLE II - Prevalence of HIV antibody in risk groups in and outside London, October 1986 to December 1987. Number positive for HIV antibody/number tested in parentheses

\begin{tabular}{|c|c|c|c|}
\hline Risk group ${ }^{\star}$ & In London & Outside London & Total \\
\hline $\begin{array}{r}\text { Homosexual or } \\
\text { bisexual men }\end{array}$ & $15 \cdot 1(213 / 1412)$ & $4 \cdot 0(146$ & $7 \cdot 2(359 / 5019)$ \\
\hline Intravenous drug user & $5 \cdot 7(36 / 633)$ & $1.5(39 / 2562)$ & $2 \cdot 3(75 / 3195)$ \\
\hline $\begin{array}{l}\text { Heterosexual partner } \\
\text { in known risk group }\end{array}$ & $1.6 \quad(8 / 515)$ & $0 \cdot 2 \quad(6 / 2757)$ & $0.4(14 / 3272)$ \\
\hline
\end{tabular}

*Within each risk group difference between London and outside was significant, $\mathrm{p}<0 \cdot 001$.

\section{Subjects and methods}

Three laboratories were in London and seven outside, together serving populations in half of the 14 regional health authorities in England. Clinicians sending serum samples to the laboratories for testing for HIV antibody completed a request form giving the reason for testing and the risk factor for infection. The serum samples were tested by a commercial assay, and reactive samples were subjected to confirmatory testing by independent methods.

\section{Results}

During the 15 months of the study 42190 new patients were screened, of whom $608(1 \cdot 4 \%)$ were positive for HIV antibody; $18284(43 \%)$ were from genitourinary medicine clinics, 10869 (26\%) from general practices, and the remainder $(13037 ; 31 \%)$ from other hospital sources.

Information was obtained for $83 \%$ of patients tested. Table I shows the prevalence of HIV antibdy according to risk group. Among intravenous drug users and subjects who had lived in Africa the prevalence was similar in men and women. Of the seven transfusion recipients with HIV antibody, only one (who had received an emergency unscreened platelet transfusion) had become infected after screening of donors for HIV antibody began in the United Kingdom. Twenty seven subjects with HIV antibody (24 women and three men) were identified among 3462 subjects whose heterosexual partner was in a high risk group or said to be positive for HIV antibody. Among the 6390 heterosexuals with a history of multiple sexual partners, only five $(0.08 \%)$ were positive for the antibody, of whom two (a man and a woman) had partners abroad. The 14065 subjects with no identified risk were tested for various reasons, including travel or insurance requirements and renal dialysis, but most were "worried" subjects who requested screening at genitourinary clinics or by general practitioners. The one subject with HIV antibody in this group was a man attending a clinic in London. 